\title{
In Search of the Real Mary Chestnut
}

\section{Citation}

Faust, Drew Gilpin, Elisabeth Muhlenfeld, and C. Vann Woodward. 1982. "In Search of the Real Mary Chestnut." Reviews in American History 10 (1) (March): 54.

\section{Published Version}

doi:10.2307/2701795

\section{Permanent link}

http://nrs.harvard.edu/urn-3:HUL.InstRepos:12008817

\section{Terms of Use}

This article was downloaded from Harvard University's DASH repository, and is made available under the terms and conditions applicable to Other Posted Material, as set forth at http:// nrs.harvard.edu/urn-3:HUL.InstRepos:dash.current.terms-of-use\#LAA

\section{Share Your Story}

The Harvard community has made this article openly available.

Please share how this access benefits you. Submit a story.

Accessibility 


\title{
IN SEARCH OF THE REAL MARY CHESTNUT
}

\author{
Drew Gilpin Faust
}

Elisabeth Muhlenfeld. Mary Boykin Chestnut: A Biography. Baton Rouge: Louisiana State University Press, 1981. xv $+271 \mathrm{pp}$. Illustrations, notes, list of sources, and index. $\$ 20.00$.

C. Vann Woodward. Mary Chestnut's Civil War. New Haven, Conn.: Yale University Press, 1981. lviii +886 pp. Illustrations and index. \$29.95.

Mary Chestnut recorded one civil war. Now, nearly a hundred years after her death, she appears to be contributing to another. When Kenneth Lynn attacked C. Vann Woodward's new edition of Chestnut's journals as a "fraud" and a "hoax," scholars seemed temporarily to abandon a longstanding interest in the historical figure behind these remarkable wartime reflections. Instead, attention turned first to this unaccustomed display of public acrimony and then to a new critical scrutiny of the text in question. Now that William R. Taylor, William Styron, Steven M. Stowe, and others have vindicated Woodward's meticulous editing of Mary Chestnut's Civil War, it may at last be possible to look beyond the document that has caused such dispute to the woman and the society that created it. The publication of Elisabeth Muhlenfeld's Mary Boykin Chestnut: A Biography encourages such a focus, for it is the first full-scale treatment of Chestnut's life before and after the dramatic years portrayed in her journal. "And just as the journal illuminates her world for the twentieth-century reader," Muhlenfeld argues, "so her life-compelling and indomitable-informs and illuminates her work" (p. 11). ${ }^{1}$

Woodward and Muhlenfeld cooperated closely on their projects, and each expresses gratitude and admiration for the other. The senior scholar has written a laudatory preface to Muhlenfeld's biography and declares her aid to have been "indispensable" to his own efforts, while she in turn offers him effusive thanks in her preface. Despite these testimonies to collaboration, the two historians' interpretations of Chestnut are quite different. Muhlenfeld's predominant interest seems to be Chestnut's postwar writings, perhaps because these literary manuscripts make up such a large proportion of her surviving personal papers. Woodward's introduction and editorial notes for 
Mary Chestnut's Civil War show him less taken with her art than with her politics. More narrowly concerned with the years between 1861 and 1865, he hails Chestnut as a feminist and a near-abolitionist, a brilliant and clearsighted individual who saw beyond her time to the wisdom of our own.

Even in the bowdlerized earlier editions of $A$ Diary from Dixie by Isabella Martin and Myrna Lockett Avary (1905), who omitted half the original manuscript, and by Ben Ames Williams (1949), who cut 100,000 words from the journals and altered countless others, the charm of Mary Chestnut was irresistible. For mid-twentieth-century readers who have lived through the civil rights and women's movements, her impassioned complaints about slavery and the patriarchal structure of southern society have only intensified her appeal. With Woodward's essentially complete version of the revised journal of the 1880s and his careful explanation of the relationship of this manuscript to the notes and jottings of the Civil War period itself we can at last be confident that our view of the era is genuinely Chestnut's and not one imposed by subsequent editorial intervention.

Yet the Mary Chestnut that Woodward's painstaking edition of the journals reveals is not quite the same woman his introductory remarks describe. Certainly the impression of her intelligence, wit, and insight is only reinforced by this expanded version of her reminiscences. Clearly, too, she is dissatisfied with much of her life in the South and with the peculiar institution of her section. But to characterize her attitudes as "abolitionist leanings" and "militant feminism" is to place her in opposition to fundamental usages and assumptions of a society she loved. While men marched off to battle to save the South, Mary Chestnut struggled in her own way to preserve the existing southern social order.

Chestnut's own sense of futility and frustration arose as much from her inability to fill the traditional women's roles of mother and homemaker as from her dissatisfaction with such delineations of male and female spheres. Her childlessness weighed heavily upon her, because she accepted the prevailing view that "women need maternity to bring out their best and true loveliness" (p. 105). She chafed, too, at not having her own household, and her most bitter complaints about her lot appeared during the times she was compelled to live, almost as a guest, in her father-in-law's home, Mulberry, near Camden, South Carolina.

In spite of her protests against male domination - "There is no slave, after all," she wrote, "like a wife" (p. 59) - Mary Chestnut's emotional satisfaction derived largely from the attentions of men-the flirtatious interest of John Manning, the knowing satisfaction in her uncanny "power to make myself loved" (p. 32). It was a male world with which Chestnut identified; men imparted status and meaning to social interaction and provided Chestnut 
with necessary affirmation of her self-worth. When she spoke, as she often did, of her "personal ambition," she referred without thinking to her husband's political advancement; his identity subsumed her own.

Chestnut's dissatisfactions with southern patriarchy were embryonic. They did not become the kind of articulate criticisms of existing relations between the sexes that would warrant the designation of "militant feminism," for part of Chestnut still accepted the notion that in crucial areas of life, men truly were superior. Mary Chestnut, who took such pride in her own intellect, meant to pay her friend Louisa McCord the highest imaginable compliment when she declared her to have "the brains and energy of a man" (p. 304).

In fact, many of Chestnut's actions during the war were directed more toward maintaining the status quo than toward launching an attack upon it. She personally took little advantage of wartime upheaval to bring about change in her own position. When Louisa McCord accomplished so much for the soldiers' hospital in Columbia, Chestnut was overwhelmed by the level of "personal responsibility" her undertaking represented. Chestnut could not imagine herself in such a role, nor was she able until the very last months of the war even to serve as an effective hospital volunteer. The "failure, illnesses, and fainting fits" brought on by the sight of suffering kept Chestnut from aiding her friend's worthy project until at last in August 1864 shame overcame her, and she offered her services in the "feeding department." Yet she retained lingering uncertainties about hospital work, especially about the propriety of exposing her younger women friends to the suggestive remarks of lonely injured soldiers.

The entry of women into other new fields filled her with even greater alarm. She greeted with scorn those "Department women" forced by financial straits to work in government bureaus. Together with Mrs. John Smith Preston, she vowed that "come what will, survive or perish-we will not go into one of the departments . . . . We will live at home with our families and starve in a body. Any homework will do. Any menial service-under the shadow of our own rooftree. Department-never!" (p. 350).

Instead, Mary Chestnut assumed two other roles. When isolated at Mulberry, she retreated from what she viewed as intolerable reality into books, particularly the fantasy world of novels, or into illness and the opium she took to cure it. In Richmond and Columbia, by contrast, she delighted in society and in her position as hostess and maitresse de salon: "at my house it is a party, day and night" (p. 549). Her husband repeatedly accused her of "too much levity," especially when the dire news of the last months of war made her festive gatherings all the more discordant. But James Chestnut did not understand the wider social purpose of what he viewed as women's gossip and extravagance. Anthropologists have frequently noted the function of 
gossip in underlining and maintaining existing norms and standards. In very much the same way as male duelling, gossip served for southern women as a means of enforcing conformity, of censuring irregular behavior by designating it scandalous. During this period of confusion and change, Mary Chestnut worked to uphold social and sexual mores, condemning lovers kissing on a train, disdaining women who were too forward, department girls who had learned "to misbehave," or widows who began courting too soon. Socialized in the belief that the ideal woman should possess a "soft, low and sweet voice" and "graceful, gracious ways," Mary Chestnut was incapable of direct challenge to southern patriarchy, for she shared too many of its values and assumptions.

Similarly, Chestnut's criticisms of slavery hardly amounted to abolitionism. Like Thomas Jefferson, she continued to benefit from the system, while enjoying the luxury of abhorring it. She reacted with no little annoyance when disruptions at the end of the war left her without the usual assemblage of personal servants. Undertaking unaccustomed household tasks, Chestnut could only think "how dreadful it would be . . . if I should have to do it all" (p. 733). As a woman, her choices in regard to slavery were certainly limited, for she herself owned no slave property to free. But even her attitudes seem to reveal more of uncertainty and ambivalence than of the kind of implacable opposition abolitionism implies. "Reading Mrs. Stowe," she wrote, "one feels utterly confounded at the atrocity of African slavery . . . . At home we see them, the idlest, laziest, fattest, most comfortably contented peasantry that ever cumbered the earth - and we forget there is any wrong in slavery at all. I daresay the truth lies between the two extremes" (p. 428). Unlike Sarah and Angelina Grimke, fellow South Carolinians who became genuinely outspoken abolitionists, Mary Chestnut was devoted above all to the South and her husband's advancement within it. Her enthusiastic support for the Confederacy served as but the clearest testimony to her ultimate loyalties.

Yet because Mary Chestnut was neither militant feminist nor abolitionist, her journal is all the more valuable. She was a woman who criticized, yet remained part of, her world, and her writing therefore reveals both the strengths and weaknesses of her society. She was not so alienated as to be an entirely unreliable observer, neither was she so enamored of the South and its peculiar institutions as to become simply a regional apologist. In her ambivalence lies the power of her appeal.

The defeat of the South she loved destroyed Chestnut's familiar world. Cling as she might to the past, Mary Chestnut was compelled by Confederate surrender to lead a new sort of life, an existence in which survival demanded that she become a different sort of person. The years between the end of the 
war and Chestnut's death in 1886 occupy nearly half of Mary Boykin Chestnut: A Biography. Unfortunately, Elisabeth Muhlenfeld has been unable to locate extensive manuscript sources detailing Chestnut's early life. Only a few childhood letters supplement memoirs written when she was well into adulthood. After her marriage to James in 1840, the record becomes somewhat richer, and Muhlenfeld is able to trace the young wife's growing "despondency," her unhappiness with her "useless existence" at Mulberry, and her grief as she gradually realized she would never bear a child. And Muhlenfeld shows well the way in which Chestnut's "own sense of worth became increasingly identified" with her husband's success; despite her rhetorical discontent, in practice Chestnut largely accepted her wifely role.

While Muhlenfeld underlines every possible evidence of antislavery sentiments in Chestnut's early life, the biographer is more cautious than Woodward about the extent and import of Chestnut's opposition to the peculiar institution. Far from leaning toward abolitionism, Chestnut, as Muhlenfeld quotes her in an 1850 letter to her husband, declared her hatred of these antislavery extremists because of their " "cant \& abuse of us . . \& worse than all their using this vexed question as a political engine \& so retarding beyond all doubt the gradual freeing of our states...'" (p. 59). Yet Muhlenfeld describes as well how Chestnut's hopes for an eventual end to slavery were coupled with a love of the luxuries human bondage made possible and with a racism that led her to regard blacks as "'dirty-slatternly-idle-ill smelling by nature'" (p. 109). At one point Muhlenfeld suggests that Chestnut's "outspoken detestation of slavery" may have served as a serious handicap in Camden society. But the biographer provides no evidence of Chestnut publicly airing her views. Her oft-quoted statements deploring human bondage all come from private journals and from letters to her husband. No surviving data suggest that South Carolinians were generally aware of her sentiments. The documentation Muhlenfeld presents reveals Chestnut as a critic of slavery unable, indeed unwilling, overtly to challenge the system.

With the destruction of the peculiar institution and the wealth upon which southern patriarchy was based, Chestnut's flirtations and frivolities, her lively social whirl, became impossible. Careful attention to every penny was now a necessity, and Mary Chestnut's butter and egg business grew to be nearly as important to the family as James's devalued patrimony of land and emancipated slaves. Under these circumstances, Chestnut lost her sense of uselessness, for she was contributing to her own and her husband's survival. And she knew she possessed as well a store of notes and memories about a period of enormous historic importance; this consciousness liberated her ambition and gave her the courage to write. Despite the difficult conditions of life in postwar South Carolina, Chestnut seemed to manifest little of the 
"despondency" that had characterized her prewar outlook. In fictional and autobiographical works and in the revision of her Civil War journals undertaken in the 1880s, Mary Chestnut, as Muhlenfeld describes her, found a vocation at last.

Yet Chestnut succeeded in selling only one newspaper sketch - for ten very needed dollars; her fiction, in Muhlenfeld's view, was promising but unrealized; her journals remained unpublished at her death. Mary Chestnut never knew her own worth. She continued to derive her fundamental identity from her husband and his achievements. When he became ill in 1884, she promptly abandoned her own literary endeavors to aid him in arranging his papers and autobiographical reflections, regarding them as far more important than her own scribblings. When she died at the age of sixty-three with the revisions of her journal unfinished, she could have had little notion of the importance it would one day assume as a window into her beloved South and the role of women within it. And how surprised she would be to think that the twentieth century would remember James Chestnut, senator, Confederate general, and statesman, primarily as Mary Chestnut's spouse.

Professor Faust, Department of American Civilization, University of Pennsylvania, is the author of The Ideology of Slavery: Proslavery Thought in the Antebellum South (1981).

1. Kenneth S. Lynn, "The Masterpiece that Became a Hoax," New York Times Book Review, April 26, 1981, pp. 9, 36; William R. Taylor and Steven M. Stowe, "Mary Chestnut's Diary," New York Times Book Review, May 17, 1981, p. 39; William Styron, "In the Southern Camp," New York Review of Books, August 13, 1981, pp. 24-26. 